\title{
Variation in the actual preferences for Al bull traits among Finnish dairy herds
}

\section{Paakala, Elina}

2018-12

Paakala , E , Martin-Collado , D , Mäki-Tanila , A \& Juga , J 2018 , ' Variation in the actual preferences for Al bull traits among Finnish dairy herds ' , Journal of Animal Breeding and Genetics , vol. 135 , no. 6 , pp. 410-419 . https://doi.org/10.1111/jbg.12359

http://hdl.handle.net/10138/322023

https://doi.org/10.1111/jbg.12359

unspecified

acceptedVersion

Downloaded from Helda, University of Helsinki institutional repository.

This is an electronic reprint of the original article.

This reprint may differ from the original in pagination and typographic detail.

Please cite the original version. 


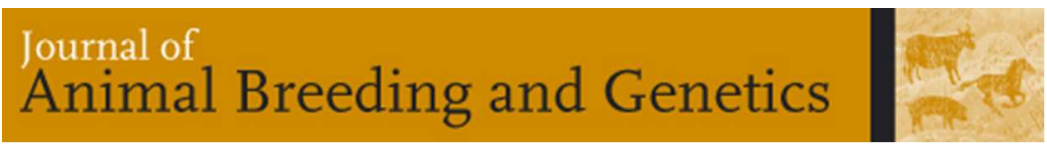

\section{Variation in the actual preferences for AI bull traits among Finnish dairy herds}

\begin{tabular}{|r|l|}
\hline Journal: & Journal of Animal Breeding and Genetics \\
\hline Manuscript ID & JABG-18-0015.R2 \\
\hline Danuscript Type: & Original Article \\
\hline Complete List of Authors: & $\begin{array}{l}\text { Paakala, Elina; Helsingin Yliopisto Maatalous-Metsatieteellinen Tiedekunta, } \\
\text { Animal Science; Faba co-op } \\
\text { Martin-Collado, Daniel; Centro de Investigacion y Tecnologia } \\
\text { Agroalimentaria de Aragon } \\
\text { Mäki-Tanila, Asko; University of Helsinki, Department of Agricultural } \\
\text { Sciences } \\
\text { Juga, Jarmo; University of Helsinki, Animal Science }\end{array}$ \\
\hline Subject Area: & $\begin{array}{l}\text { artificial insemination, breeding goal, dairy cattle, selection index, breeding } \\
\text { programme }\end{array}$ \\
\hline &
\end{tabular}




\section{Variation in the actual preferences for Al bull traits among Finnish dairy herds}

2

3 Elina Paakala ${ }^{1,2}$, Daniel Martín-Collado ${ }^{3}$, Asko Mäki-Tanila $^{1}$ and Jarmo Juga ${ }^{1}$

4

$5{ }^{1}$ Department of Agricultural Sciences, University of Helsinki, PO Box 28, 00014

6 Helsinki, Finland

$7 \quad{ }^{2}$ Faba co-op, Urheilutie 6D, 01370 Vantaa, Finland

$8{ }^{3}$ Centro de Investigación y Tecnología Agroalimentaria de Aragón, Avda. Montañana 9 930, 50059 Zaragoza, Spain

10

\section{Abstract}

Changing production circumstances, a wide range of traits and the international bull market enable dairy farmers to make increasingly specific choices concerning artificial insemination (Al) bulls. Finland is part of the joint Nordic dairy cattle breeding programme where in addition to yield, high emphasis is given to health, fertility, conformation and longevity. The aims of our study were (1) to investigate whether Finnish dairy farmers differ in their selection preferences for Al bull traits and can be clustered into herd groups, (2) to determine whether AI bull selection in different herd groups is in line with the Nordic total merit index (NTM) and (3) to analyse how the herd groups are related to herd characteristics. We used a statistical cluster analysis to analyse Al bull usage and to group herds according to each herd's bull selection profile determined by the traits' estimated breeding value (EBV) mean weighted by the number of inseminations for the various traits. We identified four herd groups in both Ayrshire (AY) and Holstein (HOL) breeds: Production, Fertility, All-rounders, and Conformation. The herds' bull selection profiles were mostly close to the NTM except in the Conformation herd groups where traits other than conformation were nearly neglected. This led to poorer expected genetic and economic outcomes than with the 
NTM selection. Conformation herds were a minority, but they were larger in herd size and investments had recently been made. The data suggest that either fine-tuning the weights in the NTM, forming alternative indices or developing a herd-specific total merit index (TMI) could fulfil the needs of very diverse herds.

Keywords: Artificial insemination, breeding goal, breeding programme, dairy cattle, selection index

\section{Introduction}

Finland, Denmark and Sweden have had a joint dairy cattle breeding programme since 2002 for the Nordic Red Breeds (Finnish Ayrshire (AY), Swedish Red and Danish Red), Holstein (HOL) and Jersey. The programme is coordinated by the artificial insemination $(\mathrm{Al})$ organization Viking Genetics and the breeding values are computed by Nordic Cattle Genetic Evaluation (NAV; Aarhus, Denmark). The joint Nordic breeding programme is based on the breed-specific Nordic Total Merit index (NTM), which guides population-level Al bull selection. Traits incorporated in the NTM are weighted according to their economic importance in the Nordic production environment (Kargo et al., 2014). In addition, farmer representatives annually reassess the weights to reflect farmer opinions, societal needs, and consumer preferences (Table 1). Yield, longevity, fertility, and health traits have always had the highest emphasis in the NTM.

National breeding goals have traditionally guided dairy farmers' bull selection in the three Nordic countries. More recently, this has been taken up by the NTM. In Finland, the majority of $\mathrm{Al}$ doses are purchased from the joint Nordic breeding programme, but the quantity of annually imported AY and HOL semen doses has notably increased in past years and is becoming quite relevant. In 2015, 10\% of the total AY breed doses (approx. 280 000, Animal Health ETT, 2016) and 30\% of the HOL breed doses (approx. 230000 sold doses) were imported from outside of the three Nordic countries carrying out the joint dairy cattle breeding programme. 
56 The Finnish dairy sector has recently experienced major changes. Since 2000, the 57 number of dairy herds has more than halved, while the total quantity of milk received by dairies has remained essentially unaltered (Ahlstedt et al., 2015). The average size of a milk-recorded dairy herd has more than doubled from 17.1 to 36.0 cows (ICAR, 2016). In the meantime, the exploitation of reproduction technologies and the rapid implementation of genomic selection have altered dairy breeding programmes across the globe. Also, the use of automatic management has increased in various stages of dairy production, and is consequently changing the profile of traits desired in a dairy cow. For example, Germany utilizes an index to describe the suitability of a bull's daughters to automatic milking systems (vit IT-Solutions for Animal Production, 2016).

Under the changing and varied production sector, the wide international market for dairy bulls and the increasing number of traits being evaluated, farmers' trait preferences are segmented and farmers can be grouped according to their various trait preferences (e.g. Martin-Collado et al., 2015; Slagboom et al., 2016). As a response to the heterogeneity in dairy farmers' trait preferences, many breeding associations and companies are developing a series of total merit indices (TMI) instead of just one common index, to meet specific farmer needs and preferences. For example, three indices (Balanced Performance Index, Health Weighted Index, and Type Weighted Index) have been introduced to the Australian dairy sector. These three indices are based on a combination of bio-economic analysis, a farmer preferences' survey, and a desired gain approach (Martin-Collado et al., 2015; Byrne et al., 2016).

The analysis of farmers' trait preferences can be used to strengthen farmer participation in a breeding programme. Nielsen et al. (2014) argued that including farmer's views in deciding the level of trade-off between production and functional traits, may enhance his or her endorsement of the breeding objectives. The implicit weighting of the traits deduced from farmers' purchase behaviour were included in the analysis of a breeding goal to find out how much farmers were willing to sacrifice in the selection response for production traits in to improve functional traits related to 
sustainability (Nielsen et al., 2005). The results showed that further genetic improvement, for e.g. functional traits, was possible by including nonmarket values (e.g. animal wellbeing and environmental impact), which were independent of current market forces in the breeding goal with only minor losses in total selection response.

When extensive national insemination records are available, they can be used to quantify the genetic and economic effect of farmers' choices among the traits when selecting Al bulls to breed their cows. Alfonso (2016) used U.S. Holstein dairy cattle insemination data to demonstrate the use of a discrete Choquet integral, an averaging aggregation function defined with respect to a fuzzy measure (e.g. Beliakov et al. 2016) in constructing an aggregate breeding goal genotype. In this method the stated preferences of decision makers are expressed as predicted breeding values of animals and the number of offspring can be considered as "realized preference" of the aggregate goal.

Analysing stated preferences (i.e. what farmers say they prefer) has to date been the main approach for investigating farmers' trait preferences, which is the only possible approach if sufficient data on the used bulls are not available (e.g. Nielsen and Amer 2007; Martin-Collado et al., 2015; Slagboom et al. 2016). However, the stated preferences' approach has certain weaknesses as we do not know how well they lead to realized choices. However, this problem can be overcome to some extent with a sound experimental design if there are enough data to analyse the realized choices (i.e. revealed preferences). For example, the stated preferences concerning consumer interests in buying a product have been seen to differ from realized choices (Morwitz, 2014). In the case of Al bulls, the difference between intention and purchase may stem e.g. from the price and availability of semen doses and the marketing strategies of breeding companies.

In Finland, there are extensive data on herd characteristics, insemination records and Al bulls' estimated breeding values (EBVs) for a wide range of traits. The actual use of Al bulls extracted from the insemination data in our current study can provide useful information on farmers' actual purchase behaviours. We analysed the data 
115 with the objectives of our study being (1) to investigate whether Finnish dairy farms

116 have differing selection preferences for Al bull traits and can be clustered into herd

117 groups, (2) to determine whether Al bull selection in different herd groups is in line

118 with the NTM of the joint Nordic breeding programme and (3) to analyse how the

119 herd groups differ in herd characteristics.

120

121 Materials and methods

122 Data

123 The analysis was based on insemination data provided by the breeding organization

124 Faba co-op (Hollola, Finland). Specifically, we analysed AY and HOL AI bull

125 inseminations of Finnish milk-recording herds in 2015. AY and HOL are the main

126 dairy breeds in Finland, constituting $55.0 \%$ and $43.3 \%$ of the total number of milk-

127 recorded cows in 2015, respectively. The dataset included 475015 insemination

128 records from 5987 herds. The quantity of Al doses imported from outside Finland,

129 Denmark, and Sweden was quite substantial (Animal Health ETT, 2016). A total of 27

130790 AY semen doses were imported in 2015, with 21323 doses used in the 2015

131 inseminations (11\% of all AY semen doses used in Finnish milk-recording herds).

132 The number of imported HOL semen doses was 66 384, just over half (37 999) of

133 which were used in inseminations during that same year $(22 \%$ of all HOL semen

134 doses used in Finnish milk-recording herds).

135 As an essential basis for our study, the insemination data were combined with bull

136 EBV information. The EBVs from the November 2015 evaluation (provided by NAV)

137 of the 14 traits included in the NTM (Table 1) were used in the analysis. Al bulls used

138 for less than 100 inseminations were excluded from the dataset, as were also the

139 bulls with missing EBVs; EBVs were missing for $31 \mathrm{AY}$ and $41 \mathrm{HOL}$ bulls. The

140 excluded bulls of both breeds were young bulls mostly from North America that had

141 been genomically evaluated in their birth country but not in the Nordic setting. The

142 final data set included 176 AY bulls and $232 \mathrm{HOL}$ bulls. The number of inseminations 
143

144

145

146

147

148

149

150

151

152

153

154

155

156

157

158

159

160

161

162

163

164

165

166

167

168

169

170

171

per bull varied considerably: 67 bulls of both breeds were used more than a thousand times, with the most popular AY and HOL bull being used 8767 and 7529 times, respectively, while $41 \mathrm{AY}$ bulls and $85 \mathrm{HOL}$ bulls were only used 100-200 times.

As Finnish dairy herds often have cows from more than one breed, we wanted to explore breed-specific bull selection. We therefore analysed the herd data separately for $\mathrm{AY}$ and $\mathrm{HOL}$ breeds by only considering herds with more than $90 \%$ of the cows of either breed. After filtering, the final data set consisted of 1279 AY herds (70 158 inseminations) and $544 \mathrm{HOL}$ herds (34 512 inseminations).

ProAgria (the Association of ProAgria Advisory Centres; Vantaa, Finland) provided herd characteristics data from 2015. We analysed 23 herd characteristics: herd size, average energy-corrected milk yield, average yield (cows and heifers), lifetime yield (live and culled cows), number of calvings per cow, calving age of heifer, calving interval, number of inseminations (cows and heifers), culling percentage (cows and heifers), cow mortality, percentage of stillborn calves, animal density per hectare of arable land, investment year of cow housing, average NTM of cows (including all cows and breeds of the herd), housing type, feeding type, milking machine type, agricultural subsidy region in Finland and whether the farm is conventional or organic (Table S3; Table S6).

Statistical analysis

A cluster analysis (CA) was performed to investigate whether the herds formed clear groups based on their bull selection profiles. To summarize a farmer's revealed preferences for Al bull traits, we defined a "herd bull selection profile" as the average of all 14 trait EBVs available for the bulls over all the inseminations in the herd. The CA was performed using R software and the k-means clustering method (MacQueen, 1967; R Core Team, 2016). The k-means clustering method is one of the most popular methods for partitioning a large number of observations into $k$ clusters based on some descriptive variables. The goal is to minimize the intra-cluster distances between variables values (here the average sire traits EBVs), while maximizing intercluster distances (Ghatak, 2017). The number of clusters $(k)$ in this method is pre- 
172 determined. Starting with a set of randomly chosen data points as initial centres an 173 algorithm is repeated where each data point is placed to the cluster whose centre 174 value is closest to the data point. The centre value is replaced with a new mean until 175 the solution does not change between two consecutive rounds. The clustering will 176 result in the pre-determined number of herd groups resembling each other and 177 differing from other groups with respect to herd bull selection profiles. The decision 178 concerning the most appropriate number of clusters was based on a comparison of 179 loss of inertia (within-cluster sum of squares) at each partitioning of clusters and on 180 the statistical testing of differences among the emerged clusters for the variables 181 considered. The CA was performed separately for the AY and HOL herds. The analyses were run by varying $\mathrm{k}$ from two to five. The statistical significance for the differences in each traits' average sire EBV between the herd clusters was tested using ANOVA with a subsequent Tukey's multiple comparison test for pairwise differences (Tukey, 1949). Four was the most meaningful number of herd clusters ("herd groups" hence forward)

187 for both AY and HOL breeds based on the aforementioned criteria. Separate CAs 188 were also implemented for herds where $40-60 \%$ of cows were either AY or HOL breed to explore how such herds possibly differed from the previous "pure" herd results.

The average sire EBV for the 14 traits in the herd groups shows the selection differential and the expected genetic gain and further the subsequent economic change in the next generation resulting from the Al bull selection. For comparison, we also calculated the expected selection differential resulting from NTM based bull selection for both breeds. In the Nordic breeding programme three percent of the 3 000 genomically tested bulls are annually selected for semen production in both breeds (VikingGenetics, 2016a, 2016b). This corresponds to a selection intensity of 2.27. The expected selection differential resulting from the NTM based bull selection for each 14 NTM trait was calculated based on the selection intensity, and the 200 201 genetic correlation between each trait and NTM (Nordic Cattle Genetic Evaluation, 2016). Most recent genetic correlations and economic values were used in the 
202

203

204

205

206

207

208

209

210

211

212

213

214

215

216

217

218

219

220

221

222

223

224

225

226

227

228

analysis. The EBV for youngstock survival was not available until 2016 and was therefore omitted from the analyses, which were based on Al bulls' EBVs from November 2015.

The economic consequences of bull selection were computed using the most recent economic values per index point estimated for the 14 NTM traits (Carlén et al., 2016). For each trait, the EBV's deviation from 100 (EBVs are published with a mean of 100 and an s.d. of 10) was divided by 2 (to calculate the value of predicted transmitting ability of the sire, assuming average dams) and multiplied by the economic value of the trait per index point. The sum of the economic values across the traits was used to express the overall economic impact of bull selection in the herd groups and, for comparison, of the NTM selection.

We analysed the herd characteristics in the AY and HOL herd groups. An average was calculated for each group for continuous herd characteristics, while an occurrence percentage was calculated for categorical herd characteristics. The statistical significance of the differences among the four herd groups was tested for each farm characteristic using ANOVA with a subsequent Tukey's multiple comparison test for pair wise differences among the groups. The chi-squared test was used to test for differences in the categorical variables.

\section{Results}

Both AY and HOL pure herds exhibited clearly differentiated herd's bull selection profiles, with quite similar herd groups in the two breeds.

\section{Ayrshire herds' bull selection profiles}

- Group 1: Production herds. A total of 452 herds, whose farmers had the highest preference for yield and growth in the bull selection compared to other herd groups (Figure 1). Farmers in this group, along with Fertility herd farmers, also favoured milkability and temperament more highly than farmers in the 
229

230

231

232

233

234

235

236

237

238

239

240

241

242

243

244

245

246

247

248

249

250

251

252

253

254

255

256

257

258

other two groups. Production herd farmers paid the least attention among the groups to udder conformation.

- Group 2: Fertility herds. A total of 393 herds, whose farmers preferred fertility, calving traits, other diseases, longevity (Figure 2) and feet and leg conformation (Figure 3) more than farmers in the other groups.

- Group 3: All-rounder herds. A total of 377 herds, whose farmers focused evenly on all traits. Udder conformation was the only exception to this, as it was emphasized the second highest by All-rounder farmers (Figure 3). Farmers in the all-rounder herds, as well as in the Fertility herds, preferred to use Al bulls with high EBVs for udder health.

- Group 4: Conformation herds. A total of 57 herds. Farmers in this group focused mostly on udder conformation, frame and claw health (Figure 3), and tended to select bulls with very low EBVs for all other traits. The average EBVs for yield, growth, fertility, other diseases, milkability and temperament of selected bulls' were below the current population average.

Production, Fertility, and All-rounder herds' farmers' selected Al bulls in a rather similar manner. Bull selection in these three groups was close to NTM-based selection but with less focus placed on yield and growth, and slightly more on fertility, udder conformation, milkability and temperament. On the contrary, farmers' bull selection in the Conformation herds deviated substantially from the NTM selection; these farmers gave far less importance to yield, growth, and longevity than in the NTM selection, while focusing more on frame and udder conformation. The Production, Fertility and All-rounder herd groups were quite equal in their share of herds (29.5-35.3\%) and inseminations (29.2-36.6\%) (Table 2). The Conformation herd group was much smaller, representing $4.5 \%$ of herds and $2.2 \%$ of inseminations.

Results for the usage of AY bulls in mixed herds (Table S2) were very similar with pure herd results: most mixed herds belonged to either Production herds (380 herds) or Fertility herds (392 herds). These two groups, along with the Conformation group (56 herds), were very similar with the pure herd groups in their bull selection profile 
259 (Table S1). The fourth group (conformation+, 37 herds) was an exception. In this

260 group conformation was highly emphasized together with yield, health, fertility,

261 longevity and milkability where as in the Conformation group other traits than

262 conformation were neglected. No All-rounder herd group was formed among the

263 mixed AY herds.

264 The expected economic impact resulting from NTM-based bull selection in AY bulls'

265 daughter's lifetime performance was $€ 102.7$. In the first three herd groups this figure

266 was very similar to the NTM-implied economic impact: $€ 98.9$ (-3.7\% compared to

267 NTM selection) per cow for Production herds, $€ 103.0(+0.3 \%)$ for Fertility herds, and

$268 € 100.2(-2.4 \%)$ for All-rounder herds. The per-cow economic change for

269 Conformation herds was negative: $€-20.8(-120.3 \%)$.

270 Conformation herds averaged the largest herd size and highest animal density per

271 hectare of arable land (Table S3). Farmers in this group had made investments on

272 their farms approximately ten years later than farmers in the other groups.

273 Conformation herds also more commonly utilized a loose-housing system, a mixed

274 ration feeding system, and an automatic milking system. Conformation and All-

275 rounder herds had cows with the highest average yield. All the yield-related herd

276 characteristics were lowest in Production herds (statistically significantly different

277 from All-rounder and Conformation herds). The calving interval in All-rounder herds

278 (411.8 d) was somewhat shorter than in the other groups (420.8-422.0 d). The

279 average herd NTM (calculated using the herd characteristics data, including all cows

280 of all breeds in the herd) was lowest for Conformation herds (-6.33) and highest for

281 All-rounder herds (0.80), with no statistically significant difference from the Fertility

282 herds (0.18).

283 Holstein herds' bull selection profiles

284 Similarly to the AY herds, the HOL herds formed four groups with similar emphasis in 285 bull selection (Table S4): 
286

287

288

289

290

291

292

293

294

295

296

297

298

299

300

301

302

303

304

305

306

307

308

309

310

311

312

313

314

- Group 1: Production herds. A total of 169 herds, whose farmers emphasized yield and growth more than farmers in the other herd groups (Figure 1). They also highly emphasized longevity.

- Group 2: Fertility herds. A total of 280 herds, whose farmers tended to select bulls with high EBVs for fertility, longevity (Figure 2) and health traits.

- Group 3: All-rounder herds. A total of 48 herds, whose farmers focused evenly on all the traits in their bull selection. Milkability was most emphasized in this herd group (Figure 1).

- Group 4: Conformation herds. A total of 47 herds, whose farmers favoured frame, udder conformation, and temperament in their bull selection (Figure 3). These farmers used bulls with a very low average EBV for all other traits, in particular for fertility (Figure 2) and health traits. The EBVs of the bulls used in this group were below the current population average for these two traits.

Udder conformation and frame were emphasized more in all the herd groups than in the NTM selection. The largest negative deviations from NTM selection in the Conformation herds occurred in fertility, health and longevity traits. Overall, Production and Fertility herds deviated least from the NTM selection. Half of the herds were categorized as Fertility herds, one-third as Production herds (Table 2) and both the All-rounder and Conformation herd groups each contained approximately one tenth of the herds. The usage of HOL bulls in the mixed herds (in which $40-60 \%$ of the cows were HOL breed) (Table S5) was very similar to that in pure HOL herds (Table S4). Most mixed herds belonged to either Production herds (328 herds) or Fertility herds (420 herds). All-rounders (49 herds) and Conformation herds (76 herds) were smaller groups.

The expected economic impact in the next generation due to the NTM-based bull selection was $€ 123.8$ for a HOL daughter's lifetime performance. The expected economic impact in the next generation due to bull selection was larger for Fertility and Production herds than in the NTM selection: $€ 141.1$ (+14.0\% compared to NTM selection) per cow in the Fertility herds and $€ 140.8(+13.7 \%)$ in Production herds. 
315 The economic impact was slightly lower in the All-rounder herds $(€ 117.4,-5.2 \%)$ and

316 even lower in the Conformation herds (€ 46.5, $-62.4 \%)$.

317 All-rounder and Conformation herds in the HOL breed averaged the largest in size 318 among the herd groups, with highest animal density per hectare of arable land and 319 the most recent investments (Table S6). The herds in these two groups more often 320 incorporated loose housing, mixed ration feeding and automatic milking, and had 321 higher average yield per cow and heifer than in the Fertility and Production herds.

322 Production, Fertility, and Conformation herds had the highest lifetime yield for culled 323 cows. Cow mortality was the highest in Conformation herds. Conformation herds had 324 the lowest (-3.32) and Production herds the highest (0.26) average herd NTM 325 (including all breeds), with the latter having no statistically significant difference 326 compared to the All-rounder herds.

\section{Discussion}

Main findings

We analysed the variation in Al bulls usage in Finnish dairy herds with over $90 \%$ of

331 the cows being either of the two main dairy breeds (AY and HOL). Using CA for the 332 Al bulls' traits EBVs, we were able to identify different herd groups. The same set of 333 four groups emerged in both breeds: Production, Fertility, All-rounder and 334 Conformation. Production, Fertility and All-rounder herds bull selection profiles 335 deviated rather slightly from the NTM and the differences between these three 336 groups were relatively small compared to how these groups deviated from the 337 Conformation groups. The Conformation groups had a low number of herds, while 338 they averaged the largest herds and the most recent investments. A tendency for the 339 production traits was exhibited, where herds with lower average yield favour bulls 340 with high yield EBV. On the other hand, herds with higher means, in the 341 Conformation group in particular, chose bulls with low EBVs in production traits when 342 concentrating on selecting bulls with high EBVs on conformation traits. 
343

344

345

346

347

348

349

350

351

352

353

354

355

356

357

358

359

360

361

362

363

364

365

366

367

368

369

370

\section{Data and methods}

The analysed data set included the insemination records from all Finnish milkrecording herds during 2015. We were able to include thousands of herds in the analyses. The data also included the EBVs of most imported bulls, and the inseminations performed by all the companies operating in Finland. This very comprehensive data set makes our results reliable and representative, with no bias caused by participation interest, which is possible in survey-based preference studies, as discussed by Martin-Collado et al. (2015).

Farmers' realized selection preferences of Al bull' traits have not previously been studied using CA on this kind of data. However, insemination data have been used in constructing an aggregate breeding goal genotype assuming that decision maker preferences can be expressed with the predicted breeding values of animals (Alfonso, 2016).

CA has been used for stated preferences of Al bull selection with the option of an analysis generated number of clusters, for example by Martin-Collado et al. (2015). The number of clusters in this method is pre-selected. Given the large number of traits in our data, we hypothesized that within-herd selection could be differentiated by the main trait classes such as production, health, fertility, conformation and longevity traits. We ran the CA by varying the number of clusters from two to five. Using two clusters separated the Conformation herds from the rest but gave no information on a favoured trait in the remaining very large herd group. We decided to use four clusters in the analysis to explore the remaining variation in the heterogeneous non-Conformation group. Using four clusters captured herd groups coinciding with the main trait classes: yield, fertility, health, and conformation. The difference between Conformation herds and the rest remained in our final result with four herd groups. Running the CA with five clusters formed herd groups with only a few traits showing statistically significant differences.

Al bull selection in different herd groups 
371 We observed differences in farmers' Al bull selection profiles between the herd

372 groups. The Conformation herd group was the most distinctive group in both breeds.

373 The rest of the herd groups had fairly similar bull selection profiles with some

374 deviations: All-rounder herds selected bulls evenly selecting for several traits,

375 whereas Production herds focused the selection on production-related traits and

376 Fertility herds on fertility and calving traits. In Conformation herds farmers focused on

377 improving frame and udder conformation with little attention to other traits.

378 Concentrating only on conformation traits may stem from these farmers being

379 content with the level of other traits in their herds. For example the average

380 phenotypic yield of HOL cows and heifers was the highest in the Conformation group.

381 The reason for the narrowly focused selection profile of Conformation herds may also

382 be based on a view that conformation traits are good indicators of longevity. A

383 conformation-related group was also seen when we analysed the diversity of

384 available Al bulls using trait EBVs as variables in the CA (results not shown here).

385 Al bull usage in the mixed-breed herds was very similar to pure herds. This implies

386 that Al bull selection is very similar regardless of the breed or breed proportions of

387 the herd. The only difference between pure and mixed herds was observed in AY,

388 where mixed herds was formed two groups, with one group highly emphasizing

389 conformation traits, while the other group focused not only on conformation traits but

390 also on other traits.

391 Comparison of Al bull selection with the NTM-based selection

392 In the Production, Fertility, and All-rounder herd groups the herd's bull selection

393 profiles deviated only slightly from the NTM selection, i.e. most farmers chose AI

394 bulls that fit the Nordic breeding goal quite well even if there were diverse Al bulls

395 available on the market. Al bull selection in the Conformation herd groups deviated

396 highly from the NTM selection, and was more extreme in AY. Nielsen et al. (2005)

397 discussed farmers' willingness to sacrifice genetic progress in production traits to

398 improve functional traits related to sustainability. Our results show how farmers are

399 willing to make compromises, such as concentrating only on conformation traits, and 
400 this resulted in negative changes in the other economically more important traits such 401 as yield and longevity. Herds' average NTM for cows was lowest in the Conformation 402 herd groups in both breeds. This indicates that these farmers have also previously 403 used Al bulls with low NTMs.

404 Within-herd deviations from NTM-based Al bull selection may slow down genetic 405 progress in the traits that are given less attention than in NTM, or accelerate it in the 406 traits that are emphasized more than in NTM. The NTM weights are close to optimum 407 in an average herd in the Nordic production environment, while individual herds may 408 benefit from tailoring the breeding objective to suit their specific conditions. Our 409 results show that the proportion of herds deviating greatly from the NTM-guided 410 selection is very low, and thereby should have minimal effect on the genetic progress 411 at the population level. Hence, the overall genetic progress in Finnish dairy herds is 412 well in line with the targeted selection defined by NTM.

413 The NTM is widely used and known among Finnish dairy farmers and our results 414 therefore represent a valid comparison for herds' bull selection profiles in different 415 herd groups. A higher selection differential in certain traits, and therefore a better 416 economic impact compared to NTM-based selection was achieved in some herd 417 groups. This can be explained by availability of bulls with higher EBVs, hence with 418 higher selection differentials, in certain traits than what is calculated for the NTM 419 based selection assuming an evenly distributed use of bulls above the truncation 420 point.

\section{Herd characteristics}

422 Group averages for the herd characteristics give insight of the farms with differing Al 423 bull selection preferences even though the within-group variation in herd 424 characteristics was rather large in both breeds (Table S3; Table S6).

425 In Conformation herds, the apparent incongruence in trait preferences between 426 conformation and other traits may be caused by these herds in both breeds 427 averaging larger in size than in the other herd groups, and also because on average 
428 farmers in these groups have invested in new loose-housing systems with milking

429 robots and total mixed ration feeding in recent years. Conformation traits are, in

430 general, valued higher in automatic milking and loose-housing than in traditional tie-

431 stall barns. The scale and technological advantages in the Conformation herds may

432 have enabled higher milk production even though the genetic level for yield is

433 probably lower in these herds because of the Al bulls used.

434 All-rounder AY herds had the highest average yield per cow. Other yield

435 characteristics were also fairly high, while calving interval was lower than in the other

436 groups. This was reflected in the breeding choices: these farmers emphasized yield

437 and fertility traits less than Production and Fertility herd farmers, possibly because of

438 their smaller need to improve the herds' genetic level in these traits. For example, a

439 high phenotypic yield may explain moving a herd's breeding objective away from the 440 yield.

441 Future

442 Our results show that Al bull selection on large, advanced and well-managed farms 443 differs from the Nordic breeding goal. In Finland, average herd size is predicted to 444 increase from 37 in 2016 to 70 cows within five years (Kallinen et al., 2016). Natural 445 Resources Institute Finland (Luke, 2017) estimates the number of dairy herds to 446 decrease from the current 7600 down to 4900 by 2022 . These predictions imply that 447 Al bull selection made on dairy farms may begin deviating away from the Nordic 448 breeding goal if large farms continue to follow the trends observed in our study. 449 However, the overall future genetic level of Nordic Al bulls will depend on the NTM 450 selection controlled by the breeding organizations in these countries.

451 Alternative TMls provide farmers the opportunity for making selection choices based 452 on their own preferences, while concurrently still following the population breeding 453 objective at large. The population-level breeding goal and TMI need to be in line with 454 farmer preferences to ensure farmer motivation in following the breeding goals and 455 utilizing the TMI in their selection decisions. In recent years farmer preferences and 456 opinions have been taken broadly into consideration when defining breeding 
457 programmes. For example, three new TMls have been developed in Australia (Byrne 458 et al., 2016), each of which guide the genetic progress in the same direction with 459 minor differences in the trait weighting.

460 According to our results, NTM is well accepted by most farmers, but fine-tuning the 461 weights could be beneficial to better fit farmers' needs. This would improve the 462 acceptance and utilization of NTM. Another option could be to develop alternative 463 TMls that all direct the genetic progress in the same direction, but have slightly 464 different weightings to better fit farmer preferences. Alternative TMls could help 465 farmers in the first three herd groups to choose Al bulls. However, this is not enough 466 to fulfil the Conformation herd farmers' needs. Our results show that conformation 467 traits were emphasised more in herds with automatic milking systems, indicating a 468 potential need for an index customised for such herds with more weight placed on 469 conformation and other traits important for automatic milking, such as milkability. 470 Development of a herd-specific TMI would fulfil the needs of very diverse herds, even 471 the Conformation herds.

472 To investigate the relationship between stated farmers' preferences and realized 473 selection of Al bulls we will design and conduct a follow-up survey-based study on 474 Finnish dairy farmers' preferences concerning farm-level Al bull selection. The results 475 of our future survey will be compared with results of our current analysis on the 476 realized utilization of Al bulls. The study will explore whether farmers actually make 477 Al bull selections based on their stated preferences and whether the Nordic breeding 478 goal matches with farmer preferences. Information on a herd's realized AI bull 479 selection could be used together with stated preferences to build a herd-specific TMI 480 to include both conscious and subconscious criteria of Al bull selection.

\section{Conclusions}

483 Our results showed heterogeneity in Finnish dairy farmers' Al bull selection, and 484 herds were clustered into distinct groups based on realized preferences. A majority of 
485 farmers follow the Nordic breeding goal closely in their Al bull selection, but selection 486 differs considerably from the Nordic breeding goal among large, advanced and well487 managed herds. We observed a link between emphasizing conformation traits in 488 herds' Al bull selection and a herd having an automatic milking system. Also, high 489 yielding herds tended to select bulls with low EBVs for yield. Fine-tuning the NTM 490 weights, and developing alternative TMls or even herd-specific TMls could provide better selection tools and improve the utilization of coordinated breeding programmes 492 in herds with diverse Al bull selection profiles.

493

494

\section{Acknowledgements}

495

The authors would like to thank Faba co-op (Hollola, Finland), NAV (Aarhus,

Denmark), and ProAgria (Vantaa, Finland) for providing the data used in the

497 analyses. This work was undertaken with financial support from Faba co-op (Hollola, Finland) and VikingGenetics (Randers, Denmark). The comments of the Subject Editor and Referee are very much appreciated.

500

501

\section{Conflict of interest statement}

502 Paakala has worked as a Development Agronomist for the Faba co-op since October 503 2011.

\section{References}

Ahlstedt, J., Jansik, C., Knuuttila, M., Koikkalainen, K., Koivisto, A., Latukka, A., 509 Liesivaara, P., Miettinen, A., Niemi, J., Pyysiäinen, J., Rantala, O., RantamäkiLahtinen, L., Sulkava, M., Tauriainen, J., Toikkanen, H., Väre, M., Wuori, O. 
511 (2016, November 12). Finnish agriculture and rural industries 2015. Retrieved 512 from http://jukuri.luke.fi/handle/10024/519301.

513 Alfonso, L. (2016). Technical note: An approach to derive breeding goals from the 514 preferences of decision makers. Journal of Dairy Science. 94, 4498-4506. doi: $515 \quad 10.2527 / j a s .2016-0685$.

516 Animal Health ETT. (2016, November 14). Naudan sperman tuonti 1995 - 2014.

517 Retrieved from https://www.ett.fi/sisalto/naudan-sperman-tuonti-1995-2014.

518 Beliakov, G., Sola, H.B., Sánchez, T.C. (2016). A Practical Guide to Averaging 519 Functions. Berlin, New York: Springer.

520 Byrne, T. J., Santos, B. F. S., Amer, P. R., Martin-Collado, D., Pryce, J. E. \& Axford, 521 M. (2016). New breeding objectives and selection indices for the Australian dairy 522 industry. Journal of Dairy Science. 99, 8146-8167. doi:10.3168/jds.2015-10747.

523 Carlén, E., Pedersen, J., Pösö, J., Eriksson, J., Nielsen, U. S., \& Aamand, G. P. 524 (2016). Youngstock survival in Nordic cattle genetic evaluation. Interbull Bulletin $525 \quad 50: 80-84$.

526 Ghatak, A. (2017). Machine Learning with R. Singapore: Springer Nature.

527 ICAR. (2017, January 4). Milk recording surveys on cow, sheep and goats. Retrieved 528 from http://www.icar.org/survey/pages/tables.php.

529 Kallinen, A., Pirttijärvi R., Saarnivaara, P, \& Heikkilä, E. (2016, October 9). Maatilojen 530 kehitysnäkymät 2022. Retrieved from http://docplayer.fi/37602439-Maatilojen$531 \quad$ kehitysnakymat-2022.html

532 Kargo, M., Hjorto, L., Toivonen, M., Eriksson, J. A., Aamand, G. P., \& J. Pedersen, J. 533 (2014). Economic basis for the Nordic total merit index. Journal of Dairy Science. $53497,7879-7888$. doi:10.3168/jds.2013-7694. 
535 Luke. (2017, October 27). Luonnonvarakeskus. Taloustohtori. Maatalouden

536

537

538

539

540

541

542

543

544

545

546

547

548

549

550

551

552

553

554

555

556

557

558

559

560 rakennekehitysennuste. Retrieved from https://portal.mtt.fi/portal/page/portal/taloustohtori/rakennekehitysennuste/aikasar ja/tuotantosuunnat.

MacQueen, J. (1967). Some methods for classification and analysis of multivariate observations. Page 281-297 in Proc. Fifth Berkeley Symp. on Math. Statist. and Prob. University of California Press.

Martin-Collado, D., Byrne, T. J., Amer, P. R., Santos, B. F. S., Axford, M., \& Pryce, J. E. (2015). Analyzing the heterogeneity of farmers' preferences for improvements in dairy cow traits using farmer typologies. Journal of Dairy Science. 98, 41484161. doi:10.3168/jds.2014-9194.

Morwitz, V. (2014). Consumers' purchase intentions and their behavior. Foundations and Trends $®$ in Marketing. 7, 181-230. doi:10.1561/1700000036.

Nielsen, H. M., Amer, P. R. \& Byrne, T. J. (2014). Approaches to formulating practical breeding objectives for animal production systems. Acta Agriculturae Scandinavica, Section A - Animal Science. 64, 2-12. doi:10.1080/09064702.2013.827237.

Nielsen, H. M., \& Amer, P. R. (2007). An approach to derive economic weights in breeding objectives using partial profile choice experiments. Animal. 1, 12541262. doi:10.1017/S1731107/000729.

Nielsen, H. M., Christensen, L. G. \& Groen, A. F. (2005). Derivation of sustainable breeding goals for dairy cattle using selection index theory. Journal of Dairy Science. 88, 1882-1890. doi:10.3168/jds.S0022-0302(05)72864-2.

Nordic Cattle Genetic Evaluation. (2016, March 27). NTM - weight factors. Retrieved from http://www.nordicebv.info/wp-content/uploads/2016/05/NTM-\%E2\%80\%93weight-factors_02052016.pdf. 
561 Nordic Cattle Genetic Evaluation. (2016, December 5). NAV routine genetic

562 evaluation of dairy cattle - data and genetic models. Retrieved from

563 http://www.nordicebv.info/wp-content/uploads/2015/04/General-description_from564 old-homepage_06052015.pdf.

R Core Team. (2016). R: A language and environment for statistical computing.

Vienna, Austria. Retrieved from https://www.R-project.org.

567

568

569

570

571

572

573

574

575

576

577

578

579

580

581

582

583

584

Slagboom, M., Kargo, M., Edwards, D., Sorensen, A. C., Thomasen, J. R., \& Hjorto, L. (2016). Organic dairy farmers put more emphasis on production traits than conventional farmers. Journal of Dairy Science. 99, 9845-9856. doi:10.3168/jds.2016-11346.

Tukey, J. (1949). Comparing individual means in the analysis of variance. Biometrics. 5, 99-114. doi:10.2307/3001913.

VikingGenetics. (2016a, November 16). About Holstein. Retrieved from http://www.vikinggenetics.com/breeds/vikingholstein.

VikingGenetics. 2016b, November 16) About VikingRed. Retrieved from http://www.vikinggenetics.com/breeds/vikingred.

vit IT-Solutions for Animal Production. (2016. November 22). Robot-index RZRobot. Retrieved from http://www.vit.de/index.php?id=milchrinder-zwsonline\&no_cache $=1 \& L=1$.

\section{Supporting information}

Table S1. Averages and standard deviations of bull selection profiles and $p$-values according to Tukey's multiple comparison test between the AY herd groups. 
585 Table S2. Averages and standard deviations of bull selection profiles and $p$-values 586 according to Tukey's multiple comparison test between the mixed herd groups for AY 587 bulls.

588 Table S3. Statistics of herd characteristics in all pure AY herds and in each of the 589 four AY herd groups.

590 Table S4. Averages and standard deviations of bull selection profiles and $p$-values 591 according to Tukey's multiple comparison test between the HOL herd groups.

592 Table S5. Averages and standard deviations of bull selection profiles and $p$-values 593 according to Tukey's multiple comparison test between the mixed herd groups for 594 HOL bulls.

595 Table S6. Statistics of herd characteristics in all pure HOL herds and in each of the 596 four HOL herd groups.

597

598

599

600

601 Table 1 Traits in the Nordic Total Merit (NMT), their correlations with NTM (Nordic 602 Cattle Genetic Evaluation, 2016) and the economic values (Carlén et al., 2016) for 603 Ayrshire and Holstein Al bulls.

\begin{tabular}{l|ll|ll|l}
\hline Trait or trait group & AY & & \multicolumn{2}{l|}{ HOL } & Description \\
\hline & Cor & EV & Cor & EV & \\
\hline Yield & 0.63 & 8.33 & 0.48 & 7.61 & Milk, protein and fat yield. \\
Longevity & 0.49 & 0.61 & 0.61 & 1.12 & $\begin{array}{l}\text { Time from first calving to end of } \\
\text { third lactation. }\end{array}$ \\
Feet \& legs & 0.33 & 0.78 & 0.19 & 1.22 & Feet and leg conformation. \\
Udder health & 0.27 & 2.78 & 0.42 & 3.55 & Mastitis resistance. \\
Udder & 0.26 & 2.78 & 0.14 & 2.54 & Udder conformation.
\end{tabular}




\begin{tabular}{|c|c|c|c|c|c|c|}
\hline & Youngstock survival $^{2}$ & 0.26 & 2.03 & 0.27 & 1.40 & $\begin{array}{l}\text { Survival of heifer calves (1-458 d) } \\
\text { and bull calves }(1-30 \mathrm{~d}) \text {. }\end{array}$ \\
\hline & Birth index & 0.25 & 1.21 & 0.35 & 1.52 & $\begin{array}{l}\text { Calf survival and calving ease, as a } \\
\text { direct effect. }\end{array}$ \\
\hline & Fertility & 0.22 & 2.26 & 0.43 & 3.15 & $\begin{array}{l}\text { Interval from first to last } \\
\text { insemination, interval from calving } \\
\text { to first insemination, and number of } \\
\text { inseminations. }\end{array}$ \\
\hline & Calving index & 0.22 & 1.04 & 0.30 & 1.72 & $\begin{array}{l}\text { Calf survival and calving ease, as a } \\
\text { maternal effect. }\end{array}$ \\
\hline & Milkability & 0.16 & 0.87 & 0.02 & 0.81 & $\begin{array}{l}\text { Herd owners' assessment or milk } \\
\text { flow data from an automatic milking } \\
\text { system. }\end{array}$ \\
\hline & Other diseases & 0.15 & 1.04 & 0.45 & 1.12 & $\begin{array}{l}\text { Resistance for metabolic, feet and } \\
\text { leg, and reproductive diseases. }\end{array}$ \\
\hline & Claw health ${ }^{3}$ & 0.05 & 0.43 & 0.36 & 0.81 & $\begin{array}{l}\text { Includes claw health data recorded } \\
\text { by claw trimmer. }\end{array}$ \\
\hline & Temperament & 0.04 & 0.26 & 0.00 & 0.30 & Herd owners' assessment \\
\hline & Growth $^{4}$ & 0.02 & 0.00 & 0.10 & 0.61 & $\begin{array}{l}\text { Carcass gain and carcass } \\
\text { conformation score. }\end{array}$ \\
\hline & Frame & 0.00 & 0.00 & -0.10 & 0.00 & Body conformation. \\
\hline & \multicolumn{6}{|c|}{${ }^{1}$ Included in NTM since 2010.} \\
\hline 605 & \multicolumn{6}{|c|}{ '2Included in NTM since 2016.} \\
\hline 606 & \multicolumn{6}{|c|}{${ }^{3}$ Included in NTM since 2011.} \\
\hline & \multicolumn{6}{|c|}{${ }^{4}$ Included in NTM since 2009.} \\
\hline
\end{tabular}


608 Table 2 Percentage of herds and inseminations in Ayrshire and Holstein herd 609 groups.

\begin{tabular}{lcccc}
\hline \multicolumn{3}{c}{ AY } & \multicolumn{2}{c}{ HOL } \\
\hline Yield herds & Herds (\%) & Inseminations (\%) & Herds (\%) & Inseminations (\%) \\
Fertility herds & 35.3 & 36.6 & 31.1 & 31 \\
All-rounder herds & 30.7 & 29.2 & 51.5 & 47.2 \\
Conformation herds & 29.5 & 32.1 & 8.8 & 12.4 \\
\hline
\end{tabular}

610 


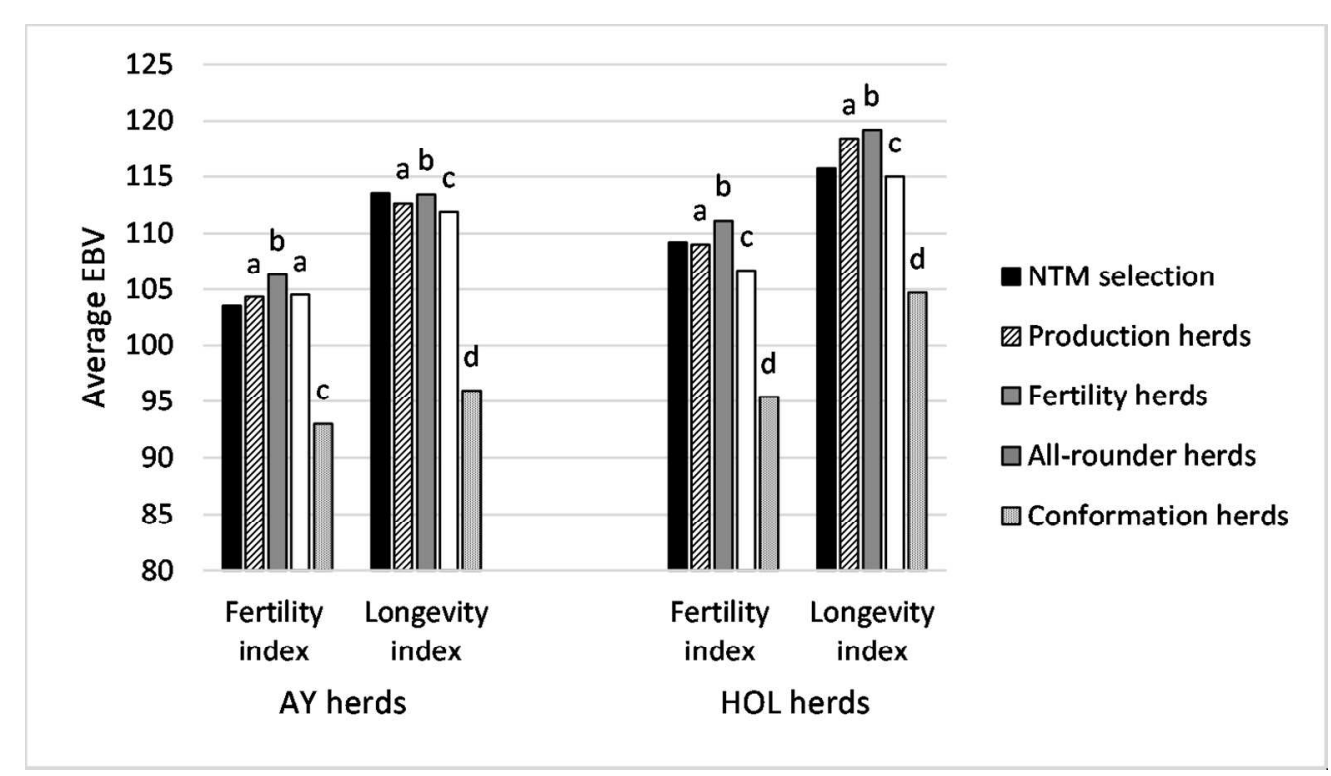

The expected genetic progress in NTM selection and mean of herd's bull selection profiles in the four different herd groups in both AY and HOL breeds in yield, growth and milkability. EBVs in the Nordic countries are scaled to an average of 100 . a-d, Averages with different superscripts within a trait and breed differ (at least with $\mathrm{P}<0.05$ ) according to Tukey's multiple comparison test.

$128 \times 73 \mathrm{~mm}(300 \times 300 \mathrm{DPI})$ 
The expected genetic progress in NTM selection and mean of herd's bull selection profiles in the four different herd groups in both AY and HOL breeds in fertility and longevity. EBVs in the Nordic countries are scaled to an average of 100 . a-d, Averages with different superscripts within a trait and breed differ (at least with $\mathrm{P}<0.05$ ) according to Tukey's multiple comparison test.

\section{$170 \times 99 \mathrm{~mm}(300 \times 300 \mathrm{DPI})$}




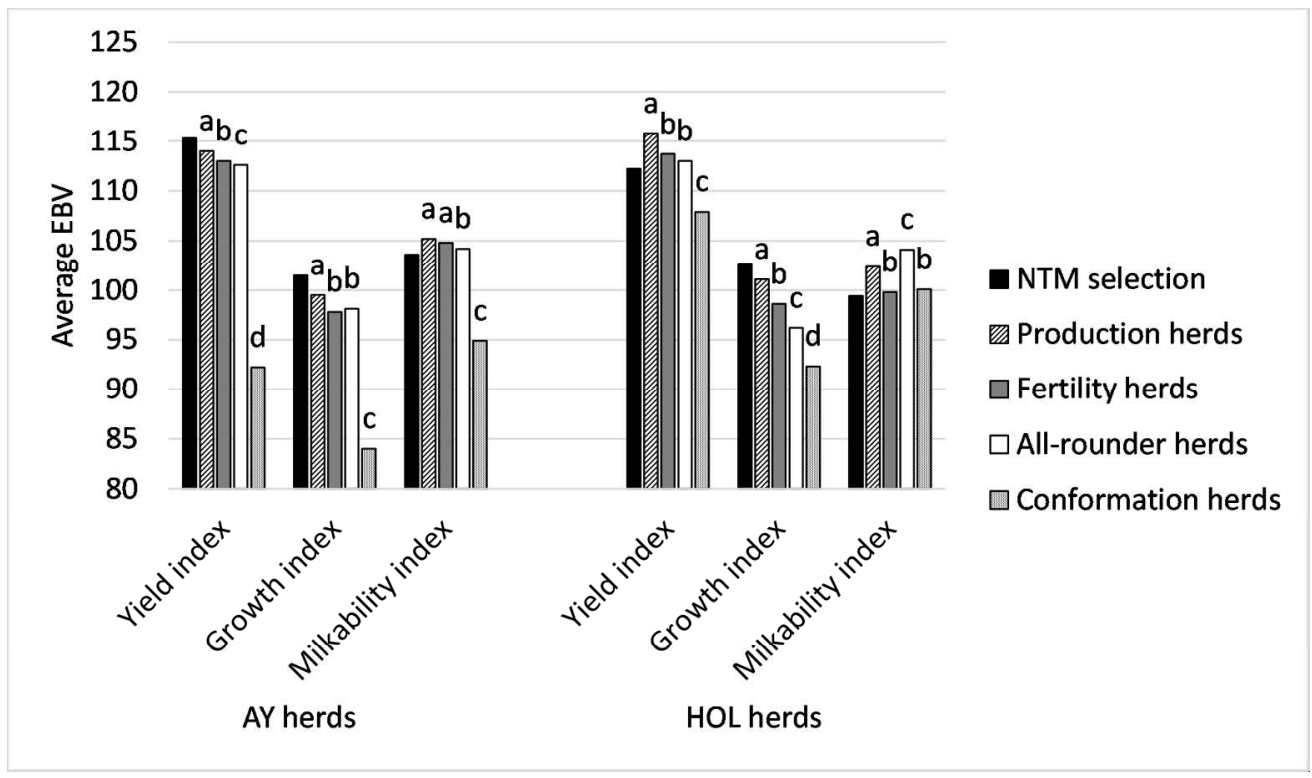

The expected genetic progress in NTM selection and mean of herd's bull selection profiles in the four different herd groups in both AY and HOL breeds in frame, feet and leg an udder conformation. EBVs in the Nordic countries are scaled to an average of 100. a-d, Averages with different superscripts within a trait and breed differ (at least with $\mathrm{P}<0.05$ ) according to Tukey's multiple comparison test.

$170 \times 99 \mathrm{~mm}(300 \times 300$ DPI $)$ 
Table S1. Averages and standard deviations of bull selection profiles (an average of the utilized Al bulls' 14 EBVs over all the inseminations in the herd) in the AY herd groups and p-values according to Tukey's multiple comparison test between the herd groups in the 14 traits included in NTM.

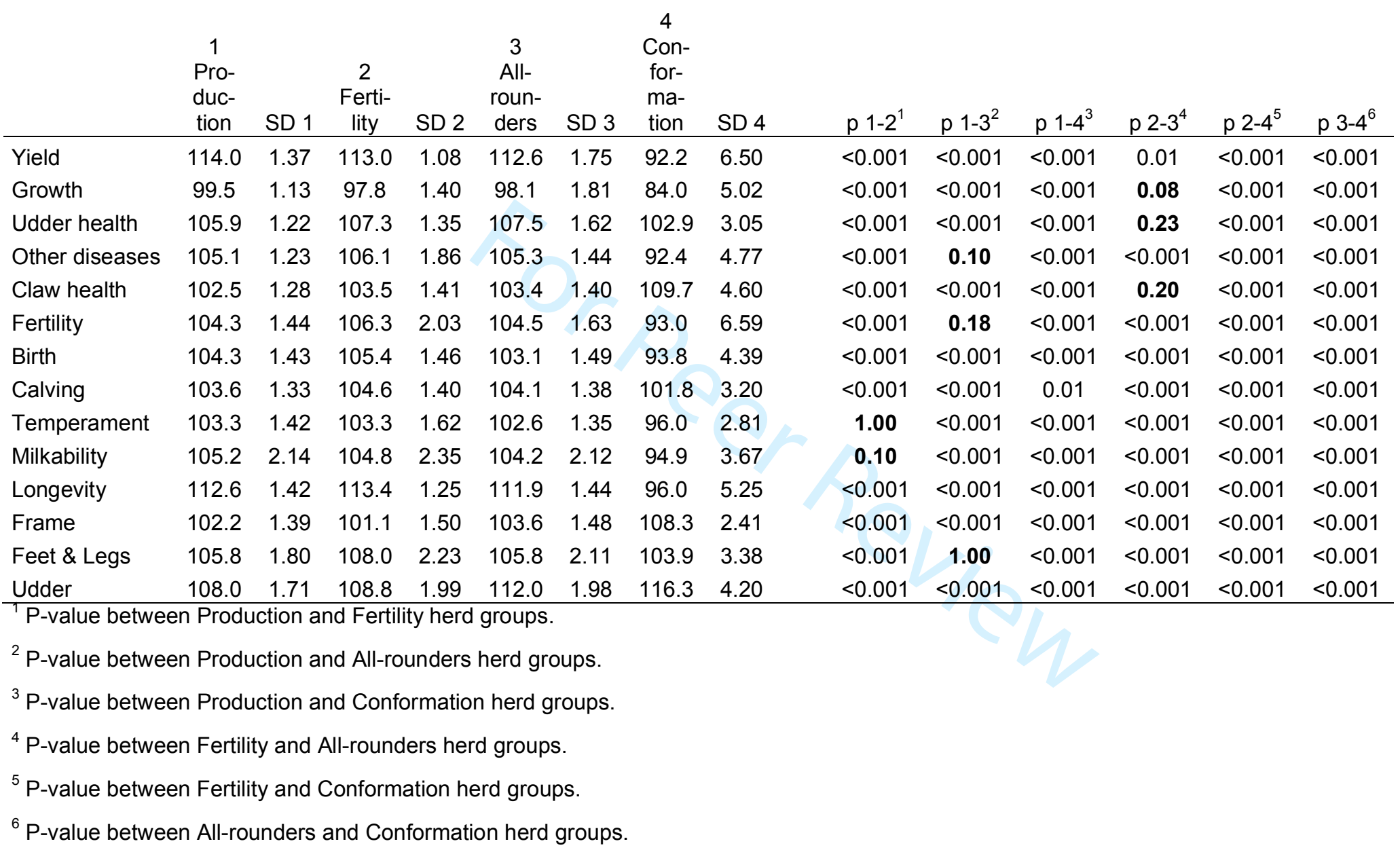


Table S2. Averages and standard deviations of bull selection profiles (an average of the utilized Al bulls' 14 EBVs over all the inseminations in the herd) in the mixed herd groups for AY Al bulls and p-values according to Tukey's multiple comparison test between the herd groups in the 14 traits included in NTM.

\begin{tabular}{|c|c|c|c|c|c|c|c|c|c|c|c|c|c|c|}
\hline & $\begin{array}{c}1 \\
\text { Pro- } \\
\text { duc- } \\
\text { tion }\end{array}$ & SD 1 & $\begin{array}{c}2 \\
\text { Fer- } \\
\text { tility }\end{array}$ & SD 2 & $\begin{array}{c}3 \\
\text { Con- } \\
\text { for- } \\
\text { ma- } \\
\text { tion+ }\end{array}$ & SD 3 & $\begin{array}{c}4 \\
\text { Con- } \\
\text { for- } \\
\text { ma- } \\
\text { tion }\end{array}$ & SD 4 & p $1-2^{1}$ & $\mathrm{p} 1-3^{2}$ & $\mathrm{p} 1-4^{3}$ & p $2-3^{4}$ & p 2-4 $4^{5}$ & p 3-4 ${ }^{6}$ \\
\hline Yield & 113.5 & 1.78 & 113.4 & 1.69 & 101.8 & 5.50 & 88.2 & 6.54 & 1.00 & $<0.001$ & $<0.001$ & $<0.001$ & $<0.001$ & $<0.001$ \\
\hline Growth & 99.0 & 2.18 & 98.7 & 1.84 & 92.1 & 4.57 & 82.1 & 6.34 & 0.18 & $<0.001$ & $<0.001$ & $<0.001$ & $<0.001$ & $<0.001$ \\
\hline Udder he & 106.7 & 1.63 & 106.7 & 1.86 & 104.9 & 2.68 & 101.1 & 3.44 & 1.00 & $<0.001$ & $<0.001$ & $<0.001$ & $<0.001$ & $<0.001$ \\
\hline Other diseases & 105.0 & 1.50 & 105.5 & 1.72 & 98.0 & 3.77 & 88.2 & 7.46 & $<0.001$ & $<0.001$ & $<0.001$ & $<0.001$ & $<0.001$ & $<0.001$ \\
\hline law health & 102.9 & 1.58 & 103.1 & 1.73 & 108.6 & 4.05 & 112.5 & 6.13 & 0.90 & $<0.001$ & $<0.001$ & $<0.001$ & $<0.001$ & $<0.001$ \\
\hline ertility & 103.8 & 1.98 & 105.2 & 2.02 & 97.9 & 4.89 & 91.6 & 6.88 & $<0.001$ & $<0.001$ & $<0.001$ & $<0.001$ & $<0.001$ & $<0.001$ \\
\hline Birth & 102.6 & 1.62 & 105.0 & 1.53 & 99.0 & 3.97 & 96.6 & 5.38 & $<0.001$ & $<0.001$ & $<0.001$ & $<0.001$ & $<0.001$ & 0.40 \\
\hline Salving & 103.9 & 1.74 & 103.9 & 1.58 & 101.9 & 2.61 & 100.8 & 4.10 & 1.00 & $<0.001$ & $<0.001$ & $<0.001$ & $<0.001$ & 1.00 \\
\hline Temperament & 103.4 & 1.67 & 102.9 & 1.93 & 98.7 & 5.60 & 97.5 & 7.57 & $<0.001$ & $<0.001$ & $<0.001$ & $<0.001$ & $<0.001$ & 1.00 \\
\hline Milkability & 106.2 & 2.56 & 104.3 & 2.65 & 98.0 & 4.01 & 93.3 & 2.06 & $<0.001$ & $<0.001$ & $<0.001$ & $<0.001$ & $<0.001$ & $<0.001$ \\
\hline Longevity & 112.3 & 1.74 & 112.8 & 1.96 & 104.1 & 4.05 & 91.7 & 5.70 & $<0.001$ & $<0.001$ & $<0.001$ & $<0.001$ & $<0.001$ & $<0.001$ \\
\hline Frame & 104.4 & 1.69 & 101.4 & 1.55 & 105.5 & 2.21 & 108.6 & 3.64 & $<0.001$ & 0.02 & $<0.001$ & $<0.001$ & $<0.001$ & $<0.001$ \\
\hline eet $\&$ & 105.3 & 2.17 & 107.1 & 2.44 & 105.5 & 4.61 & 106.7 & 5.40 & $<0.001$ & 1.00 & 0.21 & 0.74 & 1.00 & 1.00 \\
\hline Jdder & 11.1 & 2.26 & 108.2 & 2.37 & 113.8 & 4.17 & 118.4 & 4.68 & $<0.001$ & $<0.001$ & $<0.001$ & $<0.001$ & $<0.001$ & $<0.001$ \\
\hline
\end{tabular}

${ }_{1}^{1}$ P-value between Production and Fertility herd groups.

${ }^{2}$ P-value between Production and Conformation+ herd groups.

${ }^{3}$ P-value between Conformation+ and Conformation herd groups.

${ }^{4} \mathrm{P}$-value between Fertility and Conformation+ herd groups.

${ }^{5}$ P-value between Fertility and Conformation herd groups.

${ }^{6} \mathrm{P}$-value between Yield and Conformation and Conformation herd groups. 
Table S3. Mean, standard deviation, minimum and maximum of herd characteristics in all pure AY herds and in each of the 4 AY herd groups.

\begin{tabular}{|c|c|c|c|c|c|c|c|c|c|c|c|c|c|c|c|c|c|c|c|c|}
\hline \multirow{3}{*}{ Herds (n) } & \multicolumn{4}{|c|}{ All herds } & \multicolumn{4}{|c|}{1 Production herds } & \multicolumn{4}{|c|}{2 Fertility herds } & \multicolumn{4}{|c|}{3 All-rounder herds } & \multicolumn{4}{|c|}{4 Conformation herds } \\
\hline & 1279 & & & & 452 & & & & & & & & & & & & & & & \\
\hline & Mean & SD & Min & $\operatorname{Max}$ & Mean & $\mathrm{SD}$ & $\operatorname{Min}$ & Max & Mean & SD & Min & $\operatorname{Max}$ & Mean & $\mathrm{SD}$ & Min & $\operatorname{Max}$ & Mean & $\mathrm{SD}$ & Min & $\operatorname{Max}$ \\
\hline Herd size $^{1}$ & 29.0 & 19.6 & 4.7 & 197.5 & $27,8^{\mathrm{ab}}$ & 18.4 & 6.3 & 173.8 & $24,8^{a}$ & 13.9 & 4.7 & 128.0 & $30,7^{\circ}$ & 19.5 & 4.7 & 160.7 & 53.5 & 34.6 & 14.9 & 197.5 \\
\hline $\mathrm{ECM}^{2}$ & 9312 & 1426 & 662 & 12616 & $9053^{\mathrm{a}}$ & 1546 & 662 & 12616 & $9276^{a}$ & 1355 & 1412 & 12610 & 9686 & 1248 & 1231 & 12458 & $9152^{\mathrm{a}}$ & 1524 & 2180 & 11165 \\
\hline Average yield, cows ${ }^{3}$ & 8735 & 1289 & 699 & 12424 & $8459^{b}$ & 1384 & 699 & 11789 & $8678^{\text {ab }}$ & 1237 & 4017 & 12424 & $9095^{c}$ & 1153 & 2374 & 12231 & $8909^{\mathrm{ac}}$ & 1174 & 4174 & 10974 \\
\hline Average yield, heifers ${ }^{4}$ & 7723 & 1208 & 780 & 11522 & $7510^{\mathrm{C}}$ & 1278 & 780 & 10353 & $7724^{\mathrm{a}}$ & 1155 & 3634 & 11522 & $7987^{\mathrm{b}}$ & 1155 & 1466 & 10372 & $7658^{\text {abc }}$ & 1040 & 4531 & 9412 \\
\hline Lifetime yield, live cows ${ }^{5}$ & 19462 & 4805 & 6115 & 52174 & $18835^{\mathrm{b}}$ & 4893 & 6115 & 38683 & $19226^{\text {ab }}$ & 4942 & 8293 & 52174 & $20221^{\mathrm{C}}$ & 4358 & 6659 & 37428 & $20844^{\text {ac }}$ & 5086 & 12343 & 39053 \\
\hline Lifetime yield, culled cows ${ }^{6}$ & 27051 & 6981 & 4377 & 76961 & $26641^{\mathrm{a}}$ & 7338 & 6383 & 76961 & $26955^{\mathrm{a}}$ & 6984 & 4835 & 75097 & $27548^{\mathrm{a}}$ & 6513 & 4377 & 54310 & $27592^{\mathrm{a}}$ & 7047 & 15904 & 54144 \\
\hline No of calvings ${ }^{7}$ & 2.4 & 0.4 & 1.4 & 6.0 & $2,4^{\mathrm{a}}$ & 0.4 & 1.5 & 4.3 & $2,4^{\mathrm{a}}$ & 0.5 & 1.4 & 6.0 & $2,5^{\mathrm{a}}$ & 0.4 & 1.5 & 3.9 & $2,5^{\mathrm{a}}$ & 0.4 & 1.7 & 4.0 \\
\hline Calving age $^{\mathrm{b}}$ & 26.3 & 2.4 & 18.9 & 54.2 & $26,4^{\mathrm{a}}$ & 2.5 & 18.9 & 39.5 & $26,3^{\mathrm{a}}$ & 2.5 & 22.6 & 54.2 & $26,0^{a}$ & 2.1 & 20.8 & 41.2 & $26,5^{\mathrm{a}}$ & 1.8 & 23.0 & 31.9 \\
\hline Calving interval ${ }^{9}$ & 418.3 & 35.7 & 349.0 & 706.0 & $421,0^{\mathrm{a}}$ & 37.3 & 349.0 & 616.0 & $420,8^{\mathrm{a}}$ & 39.6 & 355.0 & 706.0 & $411,8^{b}$ & 29.0 & 354.0 & 575.0 & $422,0^{\mathrm{ab}}$ & 29.1 & 376.0 & 535.0 \\
\hline No of inseminations, cows ${ }^{10}$ & 1.89 & 0.41 & 1.00 & 5.25 & $1,88^{\mathrm{a}}$ & 0.40 & 1.00 & 3.43 & $1,89^{\mathrm{a}}$ & 0.40 & 1.00 & 3.60 & $1,92^{\mathrm{a}}$ & 0.43 & 1.11 & 5.25 & $1,89^{\mathrm{a}}$ & 0.42 & 1.04 & 3.23 \\
\hline No of inseminations, heifers ${ }^{11}$ & 1.61 & 0.49 & 1.00 & 8.00 & $1,61^{\mathrm{a}}$ & 0.44 & 1.00 & 3.31 & $1,61^{\mathrm{a}}$ & 0.54 & 1.00 & 8.00 & $1,61^{\mathrm{a}}$ & 0.49 & 1.00 & 5.67 & $1,67^{\mathrm{a}}$ & 0.52 & 1.00 & 3.50 \\
\hline Culling $\%$, cows $^{12}$ & 31.5 & 11.4 & 0.0 & 81.7 & $31.5^{\mathrm{a}}$ & 11.9 & 4.1 & 78.7 & $31,6^{\mathrm{a}}$ & 11.3 & 0.0 & 79.8 & $30,2^{\mathrm{a}}$ & 11.0 & 4.8 & 81.7 & $34,4^{\mathrm{a}}$ & 10.7 & 16.8 & 79.7 \\
\hline Culling $\%$, heifers ${ }^{13}$ & 18.7 & 17.1 & 0.0 & 96.8 & $19,1^{\mathrm{a}}$ & 17.3 & 0.0 & 96.8 & $18.8^{\mathrm{a}}$ & 18.0 & 0.0 & 82.2 & $17,5^{\mathrm{a}}$ & 15.4 & 0.0 & 83.3 & $23,2^{\mathrm{a}}$ & 18.0 & 0.0 & 87.7 \\
\hline Cow mortality ${ }^{14}$ & 5.2 & 5.6 & 0.0 & 35.3 & $5,0^{\mathrm{a}}$ & 5.7 & 0.0 & 35.3 & $5,3^{\mathrm{a}}$ & 5.7 & 0.0 & 30.9 & $5,2^{\mathrm{a}}$ & 5.6 & 0.0 & 34.1 & $5,5^{\mathrm{a}}$ & 4.2 & 0.0 & 14.3 \\
\hline Stillborn calves ${ }^{15}$ & 6.4 & 6.1 & 0.0 & 50.0 & $6,5^{\mathrm{a}}$ & 6.4 & 0.0 & 45.5 & $6,2^{\mathrm{a}}$ & 6.7 & 0.0 & 50.0 & $6,1^{\mathrm{a}}$ & 5.4 & 0.0 & 34.8 & $7,5^{\mathrm{a}}$ & 4.3 & 0.0 & 18.2 \\
\hline Animal density ${ }^{16}$ & 0.56 & 0.25 & 0.11 & 2.53 & $0,57^{\mathrm{a}}$ & 0.25 & 0.11 & 1.88 & $0,55^{\mathrm{a}}$ & 0.25 & 0.14 & 2.53 & $0,54^{\mathrm{a}}$ & 0.22 & 0.14 & 1.31 & 0.71 & 0.41 & 0.14 & 2.17 \\
\hline Investment year ${ }^{17}$ & 1997 & 14 & 1900 & 2015 & $1997^{\mathrm{a}}$ & 14 & 1900 & 2015 & $1996^{a}$ & 15 & 1908 & 2015 & $1997^{\mathrm{a}}$ & 12 & 1939 & 2015 & 2006 & 8 & 1980 & 2014 \\
\hline NTM $^{18}$ & -0.17 & 3.69 & -17.90 & 12.60 & $-0,39^{b}$ & 12.60 & -11.20 & 10.20 & $0,18^{\text {ab }}$ & 3.08 & -12.50 & 7.70 & $0,80^{\mathrm{a}}$ & 3.33 & -11.30 & 12.60 & -6.33 & 5.04 & -17.90 & 1.90 \\
\hline \multicolumn{21}{|l|}{ Housing type } \\
\hline Stanchion barn (\%) & 80.20 & & & & $79,40^{\mathrm{a}}$ & & & & $81,20^{\mathrm{a}}$ & & & & $70.70^{\mathrm{b}}$ & & & & $53.80^{\mathrm{C}}$ & & & \\
\hline Loose housing (\%) & 18.70 & & & & $15.70^{\mathrm{a}}$ & & & & $12.80^{\mathrm{a}}$ & & & & $22.20^{\mathrm{b}}$ & & & & $36.90^{\mathrm{c}}$ & & & \\
\hline Other (\%) & 1.10 & & & & $0.70^{\mathrm{a}}$ & & & & $1.10^{\mathrm{a}}$ & & & & $1.40^{\mathrm{b}}$ & & & & $3.30^{\mathrm{c}}$ & & & \\
\hline \multicolumn{21}{|l|}{ Feeding type } \\
\hline Separate feeding $(\%)$ & 93.70 & & & & $96,10^{\mathrm{a}}$ & & & & $95,80^{\mathrm{a}}$ & & & & $94,00^{\mathrm{a}}$ & & & & $63.50^{\mathrm{b}}$ & & & \\
\hline Mixed ration (\%) & 6.30 & & & & $3,90^{\mathrm{a}}$ & & & & $4,20^{\mathrm{a}}$ & & & & $6,00^{a}$ & & & & $36.50^{\mathrm{b}}$ & & & \\
\hline \multicolumn{21}{|l|}{ Milking machine } \\
\hline Automatic milking (\%) & 4.70 & & & & $5,00^{\mathrm{ab}}$ & & & & $2,10^{\mathrm{a}}$ & & & & $4,10^{\mathrm{b}}$ & & & & $22.60^{\mathrm{C}}$ & & & \\
\hline Milking parlors (\%) & 16.10 & & & & $13,40^{\mathrm{ab}}$ & & & & $12,50^{\mathrm{a}}$ & & & & $22,10^{\mathrm{b}}$ & & & & $22.60^{\mathrm{c}}$ & & & \\
\hline Pipeline milking (\%) & 77.30 & & & & $79,60^{\mathrm{ab}}$ & & & & $82,00^{\mathrm{a}}$ & & & & $73,30^{\mathrm{b}}$ & & & & $54.80^{\mathrm{C}}$ & & & \\
\hline Bucket milking (\%) & 1.90 & & & & $2,00^{\mathrm{ab}}$ & & & & $3,40^{\mathrm{a}}$ & & & & $0,50^{\circ}$ & & & & $0.00^{\mathrm{c}}$ & & & \\
\hline \multicolumn{21}{|l|}{ Production type } \\
\hline Conventional (\%) & 98.30 & & & & $97,80^{\mathrm{a}}$ & & & & $98,50^{\mathrm{a}}$ & & & & $98,70^{\mathrm{a}}$ & & & & $98,50^{\mathrm{a}}$ & & & \\
\hline Organic (\%) & 1.70 & & & & $2,20^{a}$ & & & & $1,50^{\mathrm{a}}$ & & & & $1,30^{\mathrm{a}}$ & & & & $1,50^{\mathrm{a}}$ & & & \\
\hline \multicolumn{21}{|l|}{ Subsidy area } \\
\hline South (\%) & 25.30 & & & & $23,10^{\mathrm{a}}$ & & & & $23,60^{\mathrm{a}}$ & & & & $28,40^{\mathrm{a}}$ & & & & $33,80^{\mathrm{a}}$ & & & \\
\hline North (\%) & 74.70 & & & & $76,90^{\mathrm{a}}$ & & & & $76,40^{\mathrm{a}}$ & & & & $71,60^{\mathrm{a}}$ & & & & $66,20^{\mathrm{a}}$ & & & \\
\hline
\end{tabular}

${ }^{2}$ Energy corrected milk yield $(\mathrm{kg})$ per cow

Milk yield (kg) per cow

${ }^{5}$ Lifetime milk yield $(\mathrm{kg})$ per cow, live cows

${ }^{6}$ Lifetime milk yield $(\mathrm{kg})$ per cow, culled cows

${ }^{7}$ Average number of calvings per cow

${ }^{8}$ Heifers calving age (months)

${ }^{9}$ Calving interval (days)

${ }^{10}$ No of inseminations per calving, cows

"No of inseminations per calving, heifers

"Percentage of planned cullings, cows

Percentage of planned cullings, heifers

Percentage of cows that die or need culling on the farm

${ }^{15}$ Percentage of calves that are stillborn or die within 7 days

${ }^{17}$ Year of latest investment on the farm 
${ }^{18}$ Average total merit index of herds cows, all breeds 
Table S4. Averages and standard deviations of bull selection profiles (an average of the utilized Al bulls' 14 EBVs over all the inseminations in the herd) in the HOL herd groups and p-values according to Tukey's multiple comparison test between the herd groups in the 14 traits included in NTM.

\begin{tabular}{|c|c|c|c|c|c|c|c|c|c|c|c|c|c|c|}
\hline & $\begin{array}{c}1 \\
\text { Pro- } \\
\text { duc- } \\
\text { tion }\end{array}$ & SD 1 & $\begin{array}{c}2 \\
\text { Ferti- } \\
\text { lity }\end{array}$ & SD 2 & $\begin{array}{c}3 \\
\text { All- } \\
\text { roun- } \\
\text { ders }\end{array}$ & SD 3 & $\begin{array}{c}4 \\
\text { Con- } \\
\text { for- } \\
\text { ma- } \\
\text { tion }\end{array}$ & SD 4 & p $1-2^{1}$ & $\mathrm{p} 1-3^{2}$ & p $1-4^{3}$ & p 2-3 $3^{4}$ & p 2-4 & p 3-4 $4^{6}$ \\
\hline Yield & 115.8 & 1.78 & 113.7 & 1.81 & 113.0 & 2.98 & 107.9 & 3.41 & $<0.001$ & $<0.001$ & $<0.001$ & 0.88 & $<0.001$ & $<0.001$ \\
\hline Growth & 101.1 & 2.20 & 98.6 & 1.78 & 96.2 & 3.63 & 92.3 & 4.58 & $<0.001$ & $<0.001$ & $<0.001$ & $<0.001$ & $<0.001$ & $<0.001$ \\
\hline Udder health & 109.6 & 1.62 & 111.3 & 1.46 & 106.4 & 2.61 & 99.7 & 3.18 & $<0.001$ & $<0.001$ & $<0.001$ & $<0.001$ & $<0.001$ & $<0.001$ \\
\hline Other diseases & 107.2 & 1.20 & 107.7 & 1.21 & 103.8 & 2.60 & 96.9 & 3.32 & $<0.001$ & $<0.001$ & $<0.001$ & $<0.001$ & $<0.001$ & $<0.001$ \\
\hline Claw health & 107.6 & 1.20 & 108.0 & 1.65 & 105.8 & 2.41 & 99.8 & 2.93 & 0.02 & $<0.001$ & $<0.001$ & $<0.001$ & $<0.001$ & $<0.001$ \\
\hline ertility & 109.0 & 2.27 & 111.1 & 2.00 & 106.7 & 3.30 & 95.4 & 5.26 & $<0.001$ & $<0.001$ & $<0.001$ & $<0.001$ & $<0.001$ & $<0.001$ \\
\hline Birth & 104.8 & 1.54 & 104.7 & 1.45 & 101.8 & 2.54 & 97.3 & 2.83 & 1.00 & $<0.001$ & $<0.001$ & $<0.001$ & $<0.001$ & $<0.001$ \\
\hline Calving & 107.7 & 1.27 & 108.4 & 1.15 & 107.2 & 3.40 & 102.3 & 3.96 & $<0.001$ & 1.00 & $<0.001$ & 0.13 & $<0.001$ & $<0.001$ \\
\hline Temperament & 104.1 & 1.88 & 103.1 & 1.59 & 105.2 & 3.00 & 107.1 & 3.20 & $<0.001$ & 0.10 & $<0.001$ & $<0.001$ & $<0.001$ & 0.04 \\
\hline Milkability & 102.4 & 2.48 & 99.8 & 1.77 & 104.1 & 4.11 & 100.1 & 3.92 & $<0.001$ & 0.08 & $<0.001$ & $<0.001$ & 1.00 & $<0.001$ \\
\hline Longevity & 118.4 & 1.41 & 119.2 & 1.74 & 115.0 & 2.73 & 104.7 & 3.28 & $<0.001$ & $<0.001$ & $<0.001$ & $<0.001$ & $<0.001$ & $<0.001$ \\
\hline Frame & 103.8 & 2.65 & 105.6 & 2.28 & 111.7 & 3.90 & 121.2 & 3.37 & $<0.001$ & $<0.001$ & $<0.001$ & $<0.001$ & $<0.001$ & $<0.001$ \\
\hline Feet \& & 105.3 & 1.72 & 106.2 & 1.74 & 106.3 & 2.60 & 104.9 & 2.33 & $<0.001$ & 0.11 & 1.00 & 1.00 & 0.01 & 0.05 \\
\hline Jdder & 113.1 & 1.77 & 114.6 & 1.65 & 116.1 & 3.29 & 117.1 & 3.07 & $<0.001$ & $<0.001$ & $<0.001$ & 0.02 & $<0.001$ & 0.74 \\
\hline
\end{tabular}

${ }^{1} \mathrm{P}$-value between Production and Fertility herd groups.

${ }^{2}$ P-value between Production and All-rounders herd groups.

${ }^{3}$ P-value between Production and Conformation herd groups.

${ }^{4}$ P-value between Fertility and All-rounders herd groups.

${ }^{5}$ P-value between Fertility and Conformation herd groups.

${ }^{6}$ P-value between All-rounders and Conformation herd groups. 
Table S5. Averages and standard deviations of bull selection profiles (an average of the utilized Al bulls' 14 EBVs over all the inseminations in the herd) in the mixed herd groups for HOL Al bulls and p-values according to Tukey's multiple comparison test between the herd groups in the 14 traits included in NTM.

\begin{tabular}{|c|c|c|c|c|c|c|c|c|c|c|c|c|c|c|}
\hline & $\begin{array}{c}1 \\
\text { Pro- } \\
\text { duc- } \\
\text { tion }\end{array}$ & SD 1 & $\begin{array}{c}2 \text { Fer- } \\
\text { tility }\end{array}$ & SD 2 & $\begin{array}{l}3 \text { All- } \\
\text { roun- } \\
\text { ders }\end{array}$ & SD 3 & $\begin{array}{c}4 \\
\text { Con- } \\
\text { for- } \\
\text { ma- } \\
\text { tion } \\
\end{array}$ & SD 4 & p $1-2^{1}$ & $\mathrm{p} 1-3^{2}$ & p $1-4^{3}$ & p 2-3 & p 2-4 $4^{5}$ & p 3-4 \\
\hline Yield & 115.5 & 2.53 & 113.7 & 1.87 & 110.2 & 3.51 & 106.4 & 2.61 & $<0.001$ & $<0.001$ & $<0.001$ & $<0.001$ & $<0.001$ & $<0.001$ \\
\hline Growth & 100.9 & 2.67 & 98.6 & 2.26 & 96.5 & 4.73 & 90.6 & 3.87 & $<0.001$ & $<0.001$ & $<0.001$ & 0.02 & $<0.001$ & $<0.001$ \\
\hline Udder health & 109.0 & 2.22 & 111.4 & 1.73 & 103.2 & 3.08 & 98.1 & 3.47 & $<0.001$ & $<0.001$ & $<0.001$ & $<0.001$ & $<0.001$ & $<0.001$ \\
\hline Other diseases & 106.8 & 1.53 & 107.7 & 1.49 & 101.6 & 2.32 & 95.1 & 3.16 & $<0.001$ & $<0.001$ & $<0.001$ & $<0.001$ & $<0.001$ & $<0.001$ \\
\hline Claw health & 107.5 & 1.74 & 108.2 & 1.85 & 103.0 & 3.35 & 97.8 & 4.70 & $<0.001$ & $<0.001$ & $<0.001$ & $<0.001$ & $<0.001$ & $<0.001$ \\
\hline Fertility & 108.3 & 2.80 & 111.2 & 2.14 & 103.0 & 4.05 & 92.8 & 4.64 & $<0.001$ & $<0.001$ & $<0.001$ & $<0.001$ & $<0.001$ & $<0.001$ \\
\hline Birth & 104.3 & 1.79 & 104.7 & 1.64 & 101.4 & 2.90 & 96.7 & 2.81 & 0.02 & $<0.001$ & $<0.001$ & $<0.001$ & $<0.001$ & $<0.001$ \\
\hline Calving & 107.6 & 1.66 & 108.2 & 1.34 & 106.2 & 2.95 & 102.1 & 4.88 & $<0.001$ & 0.01 & $<0.001$ & $<0.001$ & $<0.001$ & $<0.001$ \\
\hline Temperament & 104.4 & 2.45 & 103.0 & 1.88 & 105.6 & 3.64 & 108.6 & 3.50 & $<0.001$ & 0.12 & $<0.001$ & $<0.001$ & $<0.001$ & $<0.001$ \\
\hline Milkability & 102.8 & 2.85 & 99.6 & 2.13 & 103.2 & 4.62 & 99.8 & 4.27 & $<0.001$ & 1.00 & $<0.001$ & $<0.001$ & 1.00 & $<0.001$ \\
\hline Longevity & 117.9 & 1.75 & 119.2 & 1.88 & 110.2 & 3.30 & 102.7 & 4.01 & $<0.001$ & $<0.001$ & $<0.001$ & $<0.001$ & $<0.001$ & $<0.001$ \\
\hline Frame & 104.9 & 3.24 & 105.3 & 2.65 & 115.2 & 4.00 & 122.7 & 3.37 & 0.40 & $<0.001$ & $<0.001$ & $<0.001$ & $<0.001$ & $<0.001$ \\
\hline Feet \& Legs & 105.5 & 1.89 & 106.0 & 1.98 & 104.4 & 2.78 & 104.9 & 1.71 & 0.01 & 0.06 & 0.02 & $<0.001$ & $<0.001$ & 1.00 \\
\hline Udder & 113.3 & 2.65 & 114.5 & 2.01 & 115.9 & 4.07 & 115.9 & 3.57 & $<0.001$ & $<0.001$ & $<0.001$ & 0.17 & 0.01 & 1.00 \\
\hline
\end{tabular}

${ }^{1} \mathrm{P}$-value between Production and Fertility herd groups.

${ }^{2}$ P-value between Production and All-rounders herd groups.

${ }^{3}$ P-value between Production and Conformation herd groups.

${ }^{4} \mathrm{P}$-value between Fertility and All-rounders herd groups.

${ }^{5} \mathrm{P}$-value between Fertility and Conformation herd groups.

${ }^{6} \mathrm{P}$-value between All-rounders and Conformation herd groups. 
Table S6. Mean, standard deviation, minimum and maximum of herd characteristics in all pure HOL herds and in each of the $4 \mathrm{HOL}$ herd groups.

\begin{tabular}{|c|c|c|c|c|c|c|c|c|c|c|c|c|c|c|c|c|c|c|c|c|}
\hline \multirow[t]{2}{*}{ Herds (n) } & \multicolumn{4}{|c|}{$\begin{array}{l}\text { All herds } \\
544\end{array}$} & \multicolumn{4}{|c|}{$\begin{array}{l}1 \text { Production herds } \\
169\end{array}$} & \multicolumn{4}{|c|}{2 Fertility herds } & \multicolumn{4}{|c|}{3 All-rounder herds } & \multicolumn{4}{|c|}{4 Conformation herds } \\
\hline & Mean & $\mathrm{SD}$ & Min & $\operatorname{Max}$ & Mean & SD & Min & Max & Mean & SD & Min & $\operatorname{Max}$ & Mean & SD & Min & $\operatorname{Max}$ & Mean & SD & Min & $\operatorname{Max}$ \\
\hline Herd size $^{1}$ & 36.9 & 30.0 & 3.8 & 273.6 & $33,3^{\mathrm{a}}$ & 23.0 & 4.4 & 162.0 & $28,6^{\mathrm{a}}$ & 19.5 & 5.8 & 224.8 & $64,1^{b}$ & 49.6 & 3.8 & 273.6 & $71,1^{b}$ & 36.9 & 16.2 & 201.6 \\
\hline $\mathrm{ECM}^{2}$ & 9964 & 1367 & 2862 & 12979 & $10054^{\mathrm{a}}$ & 1289 & 5556 & 12896 & $9820^{\mathrm{a}}$ & 1323 & 5125 & 12979 & $10158^{\mathrm{a}}$ & 1428 & 6271 & 12474 & $10292^{\mathrm{a}}$ & 1724 & 2862 & 12298 \\
\hline Average yield, cows ${ }^{3}$ & 9796 & 1312 & 5105 & 13049 & $9853^{\mathrm{ab}}$ & 1307 & 5105 & 12966 & $9580^{\mathrm{a}}$ & 1281 & 5194 & 12761 & $10141^{\mathrm{bc}}$ & 1375 & 6443 & 13049 & $10529^{c}$ & 1100 & 7087 & 12713 \\
\hline Average yield, heifers ${ }^{4}$ & 8468 & 1284 & 3224 & 12151 & $8463^{\mathrm{ab}}$ & 1299 & 3955 & 11565 & $8299^{\mathrm{a}}$ & 1287 & 3224 & 12151 & $8811^{\mathrm{bc}}$ & 1141 & 6251 & 10979 & $9135^{\mathrm{c}}$ & 1090 & 6213 & 11445 \\
\hline Lifetime yield, live cows ${ }^{5}$ & 21384 & 5292 & 8077 & 39714 & $21519^{\mathrm{a}}$ & 4962 & 11370 & 39424 & $21238^{\mathrm{a}}$ & 5667 & 8077 & 39714 & $20297^{\mathrm{a}}$ & 3881 & 8874 & 31068 & $22882^{\mathrm{a}}$ & 5185 & 9492 & 33919 \\
\hline Lifetime yield, culled cows ${ }^{6}$ & 29772 & 8085 & 4166 & 74272 & $29412^{\mathrm{abc}}$ & 7478 & 9372 & 59231 & $30526^{\text {ad }}$ & 8710 & 4166 & 74272 & $26819^{\text {ce }}$ & 6663 & 13131 & 54142 & $29592^{\text {bde }}$ & 7027 & 13195 & 48586 \\
\hline No of calvings ${ }^{7}$ & 2.4 & 0.4 & 1.3 & 4.5 & $2,4^{\mathrm{a}}$ & 0.4 & 1.5 & 3.9 & $2,5^{\mathrm{a}}$ & 0.5 & 1.3 & 4.5 & $2,3^{\mathrm{a}}$ & 0.4 & 1.5 & 3.8 & $2,4^{\mathrm{a}}$ & 0.4 & 1.7 & 3.1 \\
\hline Calving age ${ }^{\triangleleft}$ & 26.3 & 2.3 & 21.4 & 44.9 & $26,2^{\mathrm{a}}$ & 2.4 & 21.4 & 39.7 & $26,5^{\mathrm{a}}$ & 2.5 & 22.5 & 44.9 & $26,1^{\mathrm{a}}$ & 1.7 & 22.9 & 30.6 & $25,8^{\mathrm{a}}$ & 1.6 & 23.4 & 31.1 \\
\hline Calving interval $^{9}$ & 418.0 & 30.6 & 353.0 & 637.0 & $415,2^{\mathrm{a}}$ & 29.2 & 371.0 & 552.0 & $419,5^{\mathrm{a}}$ & 33.4 & 353.0 & 637.0 & $417,5^{\mathrm{a}}$ & 22.7 & 380.0 & 498.0 & $420,0^{\mathrm{a}}$ & 24.9 & 379.0 & 490.0 \\
\hline No of inseminations, cows ${ }^{10}$ & 1.79 & 0.36 & 1.00 & 3.50 & $1,82^{\mathrm{a}}$ & 0.38 & 1.00 & 3.50 & $1,77^{\mathrm{a}}$ & 0.36 & 1.00 & 3.11 & $1,81^{\mathrm{a}}$ & 0.35 & 1.13 & 2.83 & $1,80^{\mathrm{a}}$ & 0.34 & 1.31 & 2.68 \\
\hline No of inseminations, heifers ${ }^{11}$ & 1.52 & 0.46 & 1.00 & 6.00 & $1,55^{\mathrm{a}}$ & 0.54 & 1.00 & 6.00 & $1,47^{\mathrm{a}}$ & 0.41 & 1.00 & 3.50 & $1,56^{\mathrm{a}}$ & 0.46 & 1.00 & 3.00 & $1,62^{\mathrm{a}}$ & 0.47 & 1.00 & 3.33 \\
\hline Culling $\%$, cows $^{12}$ & 31.9 & 10.6 & 1.8 & 82.2 & $32,3^{\mathrm{a}}$ & 10.3 & 1.8 & 55.8 & $31,7^{\mathrm{a}}$ & 10.9 & 11.4 & 82.2 & $32,2^{\mathrm{a}}$ & 10.0 & 7.9 & 57.4 & $30,9^{\mathrm{a}}$ & 10.7 & 5.8 & 65.3 \\
\hline Culling $\%$, heifers ${ }^{13}$ & 17.3 & 15.4 & 0.0 & 98.0 & $18,9^{\mathrm{a}}$ & 16.7 & 0.0 & 98.0 & $16,0^{\mathrm{a}}$ & 15.0 & 0.0 & 76.9 & $19,6^{\mathrm{a}}$ & 15.1 & 0.0 & 73.2 & $17,1^{\mathrm{a}}$ & 11.8 & 0.0 & 48.1 \\
\hline Cow mortality ${ }^{14}$ & 5.9 & 5.2 & 0.0 & 29.9 & $6,0^{\mathrm{abc}}$ & 4.9 & 0.0 & 24.1 & $5,5^{\text {ad }}$ & 5.4 & 0.0 & 29.9 & $6,1^{\text {cde }}$ & 4.1 & 0.0 & 20.7 & $7,9^{\text {be }}$ & 5.3 & 0.0 & 29.1 \\
\hline Stillborn calves & 6.4 & 6.4 & 0.0 & 65.2 & $7,0^{\mathrm{a}}$ & 8.1 & 0.0 & 65.2 & $5,7^{\mathrm{a}}$ & 5.5 & 0.0 & 25.0 & $6,6^{\mathrm{a}}$ & 5.3 & 0.0 & 21.8 & $8,3^{\mathrm{a}}$ & 4.3 & 0.0 & 19.7 \\
\hline Animal density ${ }^{16}$ & 0.60 & 0.28 & 0.02 & 2.45 & $0,59^{\mathrm{a}}$ & 0.23 & 0.02 & 1.82 & $0,56^{\mathrm{a}}$ & 0.24 & 0.10 & 2.05 & $0,75^{\mathrm{b}}$ & 0.41 & 0.27 & 2.45 & $0,80^{\mathrm{b}}$ & 0.40 & 0.18 & 2.06 \\
\hline Investment year $^{17}$ & 1999 & 12 & 1930 & 2014 & $1998^{\mathrm{a}}$ & 13 & 1930 & 2014 & $1997^{\mathrm{a}}$ & 12 & 1950 & 2014 & $2005^{\mathrm{b}}$ & 7 & 1988 & 2014 & $2008^{\mathrm{b}}$ & 5 & 1991 & 2014 \\
\hline NTM $^{19}$ & -0.71 & 3.34 & -14.50 & 11.50 & $0,26^{a}$ & 3.03 & -11.30 & 8.80 & $-0,85^{b}$ & 3.42 & -14.50 & 11.50 & $-0,68^{\mathrm{ab}}$ & 3.06 & -8.40 & 7.40 & -3.32 & 2.65 & -8.40 & 2.20 \\
\hline \multicolumn{21}{|l|}{ Housing type } \\
\hline Stanchion barn (\%) & 69.1 & & & & $68.00^{\mathrm{a}}$ & & & & $75.00^{\mathrm{a}}$ & & & & $45.80^{\mathrm{b}}$ & & & & $27.70^{\mathrm{b}}$ & & & \\
\hline Loose housing (\%) & 29.9 & & & & $26.00^{\mathrm{a}}$ & & & & $22.10^{\mathrm{a}}$ & & & & $52.10^{\mathrm{b}}$ & & & & $63.80^{\mathrm{b}}$ & & & \\
\hline \multirow{2}{*}{\multicolumn{21}{|c|}{ Feeding type }} \\
\hline & & & & & & & & & & & & & & & & & & & & \\
\hline Separate feeding $(\%)$ & 88.6 & & & & $91.40^{\mathrm{a}}$ & & & & $95.90^{\mathrm{a}}$ & & & & $63.80^{\mathrm{b}}$ & & & & $60.90^{\mathrm{b}}$ & & & \\
\hline Mixed ration (\%) & 11.4 & & & & $8.60^{\mathrm{a}}$ & & & & $4.10^{\mathrm{a}}$ & & & & $36.20^{\mathrm{b}}$ & & & & $39.10^{\mathrm{b}}$ & & & \\
\hline \multicolumn{21}{|l|}{ Milking machine } \\
\hline Automatic milking (\%) & 16.9 & & & & $17.00^{\mathrm{a}}$ & & & & $4.70^{\mathrm{a}}$ & & & & $47.90^{\mathrm{b}}$ & & & & $55.30^{\mathrm{b}}$ & & & \\
\hline Milking parlors (\%) & 15.7 & & & & $12.10^{\mathrm{a}}$ & & & & $18.20^{\mathrm{a}}$ & & & & $8.30^{\circ}$ & & & & $21.30^{\mathrm{b}}$ & & & \\
\hline Pipeline milking (\%) & 65.9 & & & & $68.50^{\mathrm{a}}$ & & & & $76.30^{\mathrm{a}}$ & & & & $39.60^{\mathrm{b}}$ & & & & $23.40^{\mathrm{b}}$ & & & \\
\hline Bucket milking (\%) & 1.5 & & & & $2.40^{\mathrm{a}}$ & & & & $0.70^{\mathrm{a}}$ & & & & $4.20^{\mathrm{b}}$ & & & & $0.00^{\mathrm{b}}$ & & & \\
\hline \multicolumn{21}{|l|}{ Production type } \\
\hline Conventional (\%) & 98.9 & & & & $100.00^{\mathrm{a}}$ & & & & $98.60^{\mathrm{a}}$ & & & & $97.90^{\mathrm{a}}$ & & & & $97.90^{\mathrm{a}}$ & & & \\
\hline Organic (\%) & 1.1 & & & & $0.00^{\mathrm{a}}$ & & & & $1.40^{\mathrm{a}}$ & & & & $2.10^{\mathrm{a}}$ & & & & $2.10^{\mathrm{a}}$ & & & \\
\hline \multicolumn{21}{|l|}{ Subsidy area } \\
\hline South (\%) & 15.1 & & & & $17.80^{\mathrm{a}}$ & & & & $13.20^{\mathrm{a}}$ & & & & $14.90^{\mathrm{a}}$ & & & & $17.00^{\mathrm{a}}$ & & & \\
\hline North (\%) & 84.9 & & & & $82.20^{\mathrm{a}}$ & & & & $86.80^{\mathrm{a}}$ & & & & $85.10^{\mathrm{a}}$ & & & & $83.00^{\mathrm{a}}$ & & & \\
\hline
\end{tabular}

2Energy corrected milk yield $(\mathrm{kg})$ per cow

Milk yield $(\mathrm{kg})$ per cow

${ }^{5}$ Lifetime milk yield $(\mathrm{kg})$ per cow, live cows

${ }^{6}$ Lifetime milk yield $(\mathrm{kg})$ per cow, culled cows

${ }^{7}$ Average number of calvings per cow

${ }^{8}$ Heifers calving age (months)

${ }^{9}$ Calving interval (days)

${ }^{10}$ No of inseminations per calving, cows

"No of inseminations per calving, heifers

"Percentage of planned cullings, cows

Percentage of planned cullings, heifers

Percentage of cows that die or need culling on the farm

${ }^{15}$ Percentage of calves that are stillborn or die within 7 days

${ }^{17}$ Year of latest investment on the farm 
${ }^{18}$ Average total merit index of herds cows, all breeds 